\title{
Groundwater age and hydrothermalism of confined aquifers in the Argentine Pampean plain

\author{
Adriana Cabrera ${ }^{1 *}$, Mónica Blarasin $^{1}$ and Luciana Maldonado ${ }^{1,2}$
}

*Correspondence:
acabrera@exa.unrc.edu.ar
${ }^{1}$ Dpto. de Geología,
Universidad Nacional de Río
Cuarto (UNRC), Ruta Nacional
$36, \mathrm{Km} 601$, Río Cuarto,
Córdoba, Argentina
Full list of author information
is available at the end of the
article

*Correspondence: acabrera@exa.unrc.edu.ar Dpto. de Geología, Universidad Nacional de Rio 36, Km 601, Río Cuarto, Córdoba, Argentina article

\begin{abstract}
The Pampean plain of Cordoba province (Argentina) has hydrothermal manifestations linked to Cretaceous depocenters. However, they are in general neither well known nor carefully used, and, in numerous cases, they are unjustifiably wasted. The objective of this work is to show the most outstanding hydrogeological features and the geologic setting that control the low enthalpy hydrothermal deep systems and groundwater age in the Pampean plain of Cordoba province. To perform the study, conventional geological and hydrogeological methodologies were used. Isotopic $\left({ }^{18} \mathrm{O},{ }^{2} \mathrm{H},{ }^{3} \mathrm{H},{ }^{13} \mathrm{C}\right.$ and ${ }^{14} \mathrm{C}$ ) and geochemical studies $\left(\mathrm{Cl}-\mathrm{SO}_{4}-\mathrm{HCO}_{3}\right.$ and $\mathrm{Na}-\mathrm{K}-\mathrm{Mg}$ ternary diagrams) were made to evaluate groundwater age and hydraulic and geochemical features of the aquifer system. The confined aquifer systems (CASs), located at 120-350 m depth, are multilayered and linked to fluvial Neogene paleosystems. The isotopic analysis for these hydrothermal systems shows that groundwater is not related to magmatic waters and it has a meteoric origin being recharged in the mountain and piedmont western areas (Comechingones Mountains). The ${ }^{14} \mathrm{C}$ ages obtained for A1 and A2 CASs indicate waters recharged during Holocene cold periods, between the "Little Ice Age" and the ending of "Holocene Climatic Optimum," and during the last glaciation, respectively. The groundwater temperatures in the discharge points are between 24 and $38^{\circ} \mathrm{C}$, which exceeds $4-12^{\circ} \mathrm{C}$ the expected value for that depth, if normal gradients are considered. The analysis using geothermometers showed that the groundwater samples were located in the immature water field near the boundary of the partially equilibrated waters. The thermal anomaly is linked to the Cretaceous depocenters of General Levalle, especially associated to the low block of the Tigre Muerto regional fault. This geothermal anomaly shows agreement with the regional geotectonic setting and it should be the result of the continental crustal thinning and the geological regional faults that make easy groundwater circulation to several depths. The groundwater flowing from recharge areas, favored by the structure of dipping regional blocks, would be reached higher temperatures (the order of $79^{\circ} \mathrm{C}$ ) explaining the present oversaturation in $\mathrm{SiO}_{2}$, what implies maximum depths of up to $1500 \mathrm{~m}$ and the observed thermodynamic behavior of such mineralogical phases. This general framework is in agreement with the $\mathrm{Cl}-\mathrm{SO}_{4}-\mathrm{HCO}_{3}$ ternary diagram which indicates steam-heated waters.
\end{abstract}

Keywords: Hydrothermalism, Groundwater age, Confined aquifer, Cretaceous depocenters 


\section{Background}

In the twentieth century, high-temperature water resources have been used for the production of electricity, whereas medium and low temperature resources are used for domestic heating, from individual houses to whole communities, as well as for balneology, industrial, and agricultural purposes (Albu et al. 1997; Stober and Bucher 2013). The utilization of geothermal energy provides an opportunity to decrease the dependency on fossil sources of energy. The substitution of fossil-fired installations leads to a reduction of $\mathrm{CO}_{2}$ emission and decreases climatic warming. The task to assess a geothermal energy potential includes geological, hydrological, technological, infrastructural, economical, and ecological investigations. In this sense, the basic hydrogeological studies in a geological basin are essential due to knowledge requirements about the spatial distribution of aquifer layers and groundwater flow, age and geochemistry, to have data for a sustainable management of such an important resource. For this reason, all around the world scientists are investigating thermal waters (Albu et al. 1997; Stober and Bucher 2013; Vasilyev et al. 2016).

Numerous hydrothermal manifestations were identified in Argentina (Pesce 2008). In Cordoba province, according to Cabrera et al. (2012a, b), Chiodi et al. (2014), and Blarasin et al. (2014), the most important manifestations are located in the area of Sierras Chicas Mountains (near Villa Giardino and Capilla del Monte towns), in Traslasierra area (near El Quicho, Serrezuela, and Piedrita Blanca towns) and in the east plain of Cordoba province (San Basilio, General Soler, and La Carlota towns, among others). All of them are low enthalpy geothermal systems. In the large plain of the South of Cordoba province, these systems are associated to a Cretaceous depocenter. The geological framework is supported by several geological and geophysical data, especially those resulting from oil and mining explorations in Cordoba province, which enabled the researchers to obtain information about the geological characteristics up to $7000 \mathrm{~m}$ deep. It is worth highlighting the deep geological studies carried out during oil exploration in General Levalle area (Cordoba province) by the Argentine Geological and Mining Service (SEGEMAR) in agreement with the Australian Geological Service (Pieters and Skirrow 1997), Hunt Oil and YPF Company (Chebli et al. 1999; Webster et al. 2004; Reinante et al. 2014; Calegari et al. 2014; Sigismondi and Fantín 2014). Also, the results obtained by National Universities (Degiovanni et al. 2005; Rapela et al. 2007; Rapela and Baldo 2014) have been considered. In addition to the geological importance these thermal systems have, they represent great socio-economic potential resources that can be used either for tourism or some productive enterprises. However, they are in general neither well known nor carefully used, and in numerous cases, they are unjustifiably wasted (Cabrera et al. 2010; Blarasin et al. 2014). That is why conceptual hydrogeological models of these hydrothermal systems are needed, which can become the basis for their sustainable use.

\section{Objective}

Taking into account that the groundwater data will be useful for water managers that must carefully plan their use, the objective of the present work is to show the most outstanding hydrogeological features and the geological setting that controls the low 
enthalpy hydrothermal deep systems and groundwater age in the Argentinian Pampean plain.

\section{Study area}

The research area is located in the South of Córdoba province, in Argentina (Fig. 1). It is a vast rural area in the Pampean plain, apt for farming and cattle raising, which is located about $80 \mathrm{~km}$ East to the Comechingones Mountains. There are also some small villages and towns, being San Basilio the most important, with 3160 inhabitants, according to INDEC (National Institute of Statistics and Population) 2010 Survey.

The climate in this area is subhumid mesothermal, with an average rainfall, temperature, and potential evapotranspiration of $809 \mathrm{~mm}, 16.5{ }^{\circ} \mathrm{C}$, and $822 \mathrm{~mm}$, respectively (Cabrera et al. 2010). People develop different economic activities using groundwater resources. The unconfined aquifer, the most used in the region, has poor quality water while deep aquifer systems, with good quality and thermal water, have become valuable resources for the area (Cabrera et al. 2010; Blarasin et al. 2014). However, in many situations, due to cultural reasons or "hydromyths," people have kept them permanently open to supply artificial lagoons for more than 50 years, wasting in this way a valuable resource (Fig. 2).

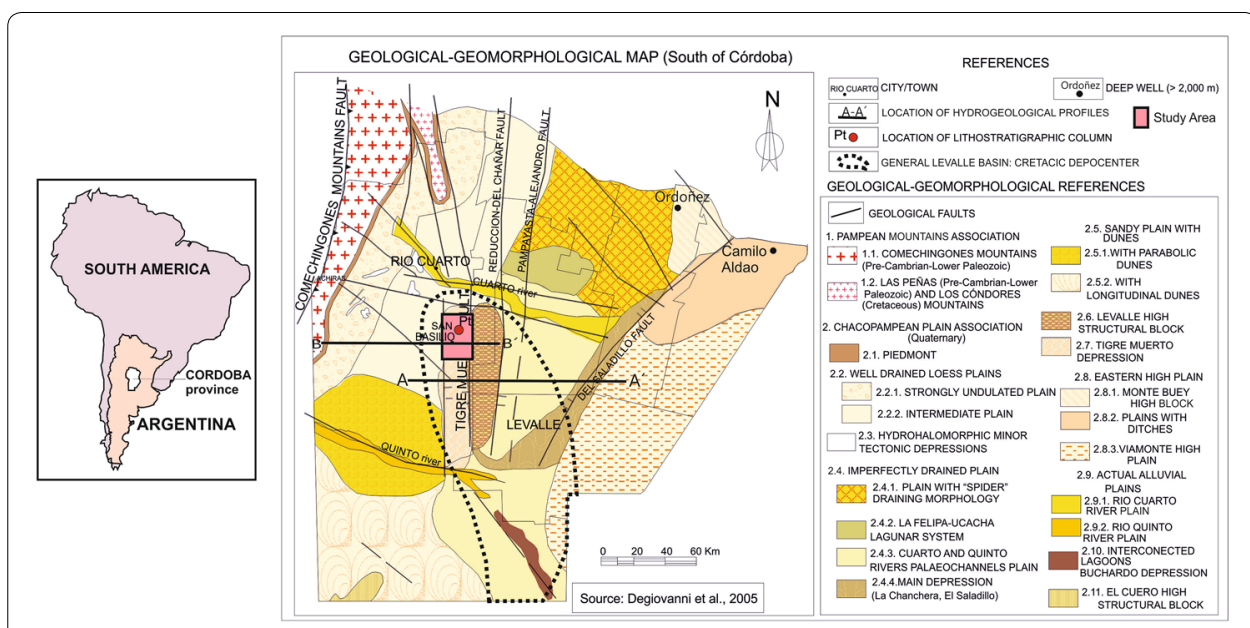

Fig. 1 Location of the study area

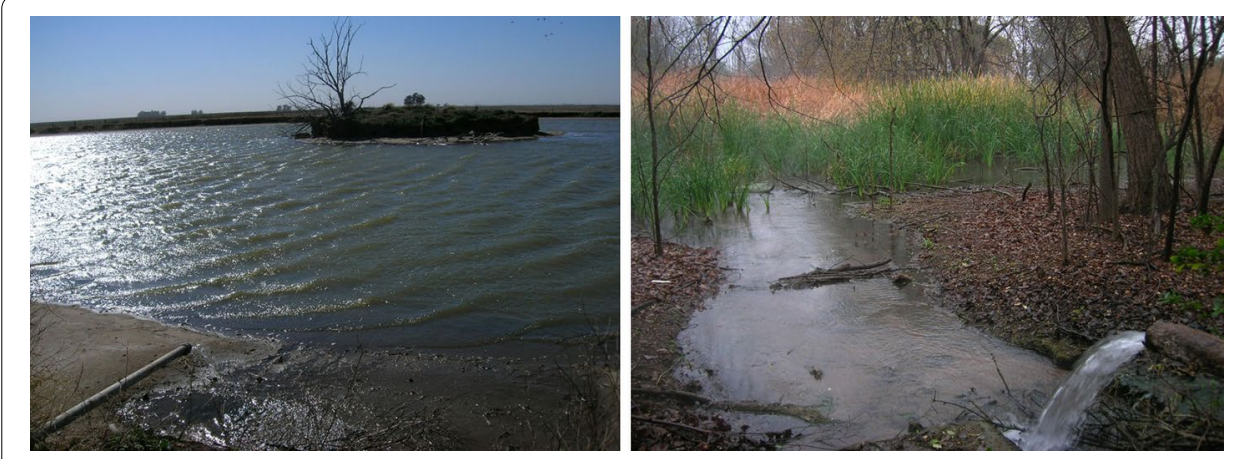

Fig. 2 Artesian wells with high-quality thermal water permanently open for more than 50 years 


\section{Methods}

The geological analysis was carried out at 1:100,000 scale on the basis of topographical charts from the National Geographic Institute (IGN) and satellite images (IGN and Google Earth). The deep geological framework interpretation (up to $7000 \mathrm{~m}$ deep) was carried out according to background regional studies in Córdoba province. Thus, the analyzed information corresponds to four deep wells which penetrated the sedimentary column and reached the bedrock: Ordoñez well (3402 m), Santiago Temple well (1100 m), Saira well (2700 m), and Camilo Aldao well (2300 m) (Rapela et al. 2007; Rapella and Baldo 2014).

Stratigraphic profile presented in the Río Cuarto Geological Worksheet (Degiovanni et al. 2005) was considered. The description of this profile was based in the results obtained by the Hunt Oil Company in Levalle area (Córdoba) where a deep well (5179 m) which did not reach the bedrock was drilled (Chebli et al. 1999; Webster et al. 2004; Reinante et al. 2014; Calegari et al. 2014; Sigismondi and Fantín 2014).

To improve the interpretation of the different aquifer levels, deep sediment profiles (up to $350 \mathrm{~m}$ ) were assessed. The sediment samples obtained from drillings were treated and subjected to textural analysis. Then, stratigraphical correlations and paleoenvironmental regional interpretations were carried out. After that, hydraulic conductivity (K) values were estimated for the different sedimentary layers using empirical granulometric methods such as (a) Sheelheim equation, to estimate $\mathrm{K}$ with the average particle size (Schafmeister 2006); (b) Slichter equation, which base the calculus on 0.01-5 mm particle size (Pérez et al. 2014); and (c) Profile Sieve Percentage (PGP) (Pérez et al. 2014), which uses triangular diagrams based on the model proposed by the United States Department of Agriculture and considers both fine and coarse fractions. The results of these estimations were compared with K tables (Custodio and Llamas 1996) and background hydraulic tests data obtained by other authors in this region (Blarasin et al. 2014; Maldonado et al. 2016).

This hydrogeological study included geochemical and isotopic analysis of rainfall and of every hydrological system (surface water, such as streams and lagoons, and groundwater, i.e., unconfined and confined aquifers). Groundwater level depths were measured in the field by means of water level meters, using manometers in artesian wells. Water samples were taken following standard methods and water quality parameters such as electric conductivity (CE), $\mathrm{pH}$, temperature, and dissolved oxygen (DO) were measured in situ. The selected samples belong to wells with short screen lengths (less than $10 \mathrm{~m}$ ) so that they are considered adequate for the interpretation of groundwater behavior at different depths, preventing water mixtures from different aquifers.

Main dissolved ions $\left(\mathrm{CO}_{3}^{-2}, \mathrm{HCO}_{3}^{-}, \mathrm{SO}_{4}^{-2}, \mathrm{Cl}^{-}, \mathrm{Na}^{+}, \mathrm{K}^{+}, \mathrm{Ca}^{+2}, \mathrm{Mg}^{+2}\right)$ were analyzed at the laboratory of the Geology Department at the National University of Río Cuarto, using standard methods (APHA, AWWA, and WPCF 2005). $\mathrm{CO}_{3}^{-2}$ and $\mathrm{HCO}_{3}{ }^{-}$through potentiometric titration with $0.01 \mathrm{~N} \mathrm{HCl}$ using a Hanna $\mathrm{pH}$-meter to indicate the end point. $\mathrm{SO}_{4}^{-2}$ was measured by gravimetric method and $\mathrm{Cl}^{-}$by titration with a potassium chromate indicator and $0.01 \mathrm{~N}$ silver nitrate titrant solution to indicate the end point. $\mathrm{Na}^{+}$and $\mathrm{K}^{+}$were determined by the flame emission photometric method and $\mathrm{Ca}^{+2}$ and $\mathrm{Mg}^{+2}$ by titration with $0.02 \mathrm{~N}$ ethylenediamine tetra-acetic acid (ETAA) titrant solutions. The indicator for $\mathrm{Ca}^{+2}$ was $\mathrm{NaOH}$ and ammonium purpurate, and the indicators 
for $\mathrm{Mg}^{+2}$ were ammonia buffer solution and eriochrome. $\mathrm{SiO}_{2}$ and $\mathrm{Li}$ were analyzed by Perkin Elmer Sciex ELAN 9000 ICP/MS at the Activation Laboratory Ltda. (ActLab) in Canada. Samples were filtered with 45-micron filter and acidified prior analysis. Detection limit for Li was $1 \mu \mathrm{g} / \mathrm{L}$ and for Si $0.2 \mathrm{mg} / \mathrm{L}$.

The stable isotopes $\left({ }^{18} \mathrm{O},{ }^{2} \mathrm{H}\right)$ and ${ }^{3} \mathrm{H}$ were determined at the Institute of Geochronology and Isotopic Geology (INGEIS-CONICET-UBA), whereas ${ }^{13} \mathrm{C}$ and ${ }^{14} \mathrm{C}$ were carried out at the Environmental Isotopic Laboratory (uWEILAB) at the University of Waterloo in Canada. ${ }^{18} \mathrm{O}$ and ${ }^{2} \mathrm{H}$ analyses were performed by means of a "Off-axis integrated cavity Output Spectroscopy" (OICOS) (Lis et al. 2008) and DLT-100 liquid-water isotope analyzer from LGR inc. Results were expressed in the usual form i.e., $\delta(\%)$. Uncertainties are $\pm 1 \%$ for $\delta^{2} \mathrm{H}$ and $\pm 0.3 \%$ for $\delta^{18} \mathrm{O}$, and reference standard is V-SMOW (Gonfiantini 1978).

In addition, selected wells were sampled for ${ }^{3} \mathrm{H}$ and ${ }^{14} \mathrm{C}$ determination, to obtain representative values of different aquifer systems. Samples were prepared following the laboratory instructions. Samples for ${ }^{3} \mathrm{H}$ analysis were collected in $600-\mathrm{mL}$ polyethylene bottles, while those for $\delta^{13} \mathrm{C}$ and ${ }^{14} \mathrm{C}$ were collected in 150 -ml polyethylene bottles. All the samples were shipped in ice coolers. The ${ }^{3} \mathrm{H}$ was determined by liquid scintillation counting after electrolytic enrichment. The detection limit was of $0.8 \pm 0.3$ tritium units (TU). ${ }^{14} \mathrm{C}$ and ${ }^{13} \mathrm{C}$ samples were analyzed by an accelerator mass spectrometer (AMS).

${ }^{14} \mathrm{C}$ results are expressed as percent of modern carbon $(\mathrm{pmC})$ relative to the National Institute of Standards and Technology (NIST). ${ }^{14} \mathrm{C}$ standard was SMR-4990C and normalized to $\delta^{13} \mathrm{C}-25 \%$. Reference standard for $\delta^{13} \mathrm{C}$ is V-PDB (Craig 1957), and the uncertainty is of $\pm 0.2 \%$.

The analysis of radioactive isotopes for the different confined aquifers made it possible to estimate groundwater ages, which were later corrected by means of Tamers (1975) and Pearson-Gonfiantini (in Salem et al. 1980) methods. The first method considers a chemical correction of the initial activity $\left({ }^{14} \mathrm{~A}\right)$, and the second method involves chemical and isotope issues. The isotopic ages were checked with the hydraulic method estimation based on the groundwater flow velocity (using Darcy Law) and on the distance to the recharge perimountain area (Kazemi et al. 2006). To compare the estimated ages, other indirect methods were used such as stable isotopes values $\left(\delta^{2} \mathrm{H}\right.$ and $\delta^{18} \mathrm{O}$, Kazemi et al. 2006).

The chemical geothermometers have been used to estimate the subsurface temperatures of the geothermal fluids. The $\mathrm{SiO}_{2}$ (Fournier et al. 1974), $\mathrm{Na} / \mathrm{K}$ and $\mathrm{Na} / \mathrm{K} / \mathrm{Ca}$ (Fournier and Truesdell 1973), Na/Li (Fouillac and Michard 1981), and Mg/Li (Kharaka and Mariner 1989) geothermometers were calculated. The saturation rates were determined with respect to the silica phase. The interpretation of these geothermometers led us to think in an initial assessment of the presence of a deep high temperature resource in a geothermal system, but it is necessary to consider the water-rock interaction condition. Thus, the $\mathrm{Cl}-\mathrm{SO}_{4}-\mathrm{HCO}_{3}$ ternary diagram was used for the classification of the thermal fluids as a first step to describe a geothermal system. This diagram can help to define whether the geothermometers are applicable for the given water sample (Giggenbach 1991), as most solute geothermometers work only for neutral water or mature water that is characterized by high $\mathrm{Cl}^{-}$and low $\mathrm{SO}_{4}{ }^{-}$(Sekento 2012). This diagram is helpful in providing an initial indication of mixing relationships or geographical 
groupings. Therefore, the $\mathrm{Na}-\mathrm{K}-\mathrm{Mg}$ ternary diagram (Giggenbach 1986) was used for the evaluation of equilibrium between the thermal waters and rocks at the studied depth and to determine the reliability of the used thermometers. The maximum depths reached by the hydrothermal fluids were estimated. Finally, the analysis of all the information led to the geochemical, isotopic, and geothermal regional model.

\section{Results and discussion}

\section{Geology}

The Pampean plain in the south of Cordoba is part of a sedimentary basin whose varied topography is related to the presence of differentially tilted and sunken structural blocks. This basin shows a tectonic inversion from an extensional regime happened at the end of the Mezosoic to a compressive one in the Paleogene (Chebil et al. 1999). The plain covers part of the sedimentary basin called Chacoparanaense basin and minor depocenters such as the one in General Levalle. This depocenter, where the studied area is located, is linked to the regional cretaceous extension of the Gondwana supercontinent. In this sector, this regime was manifested as a process of active rifting related to the opening of the South Atlantic Ocean. The basin is bounded by extensional faults that are linked to an area of cortical weakness and limited by different ages and composition bedrock, as result of the suture between the Río de la Plata Craton and Pampia terrain (Calegari et al. 2014). It is part of the central Pampean rift system (Ramos 1999), filled with continental, alluvial, and lacustrine sedimentary successions (Webster et al. 2004). Calegari et al. (2014), based on seismic information, estimate that the sedimentary column could exceed 6000-m thick in the deeper sectors. The basin has a cortical attenuation which gives rise to a gravimetric anomaly linked to a crustal thinning and not the thick sedimentary column. Moreover, in the gravimetric profiles it is clearly observed that where it should be a gravimetric minimum due to the presence of a depocenter, there is actually a high (Calegari et al. 2014). Furthermore, chemical and isotopic analyses of rocks obtained in the mentioned deep boreholes from YPF Company (Ordoñez, Saira, Santiago Temple and Camilo Aldao) show the presence of granitic rocks enriched in lithophile elements of long ionic radio as $\mathrm{Cs}, \mathrm{Rb}, \mathrm{Ba}, \mathrm{Th}, \mathrm{U}, \mathrm{K}$, but depressed in elements such as Nb, Ta, Y, and Zr (Rapela et al. 2007; Rapela and Baldo 2014). Although this pattern is typical of basic rocks formed in arc environments (subduction zone), the larger development observed in the Ordoñez well suggests an arc origin and emplacement in continental crust.

In this geotectonic regional model, the studied area is part of a fallen megablock associated to the regional Tigre Muerto Fault (NS direction) that dips to the south/southeast (Figs. 1, 3). This regional fault has originated an important incidence in the topography, which in turn has conditioned the pre-quaternary and quaternary sedimentary processes and the regional hydrological behavior (Cabrera et al. 2010; Blarasin et al. 2014).

In the litho-stratigraphical column up to a depth of $100 \mathrm{~m}$, there is a predominance of quaternary aeolian sediments (very fine silty sands) with layers of cemented silts (calcretes) and fine and medium sands and clayish sands that are subordinated and associated to the fluvial belts (Fig. 4). Between the depths of 100 and $350 \mathrm{~m}$, the sediments are from the Upper Neogene-Miocene. Levels of cemented silts, clayish silts, and clays that intercalate with fine, medium, and coarse sands and gravel lenses may be distinguished. 


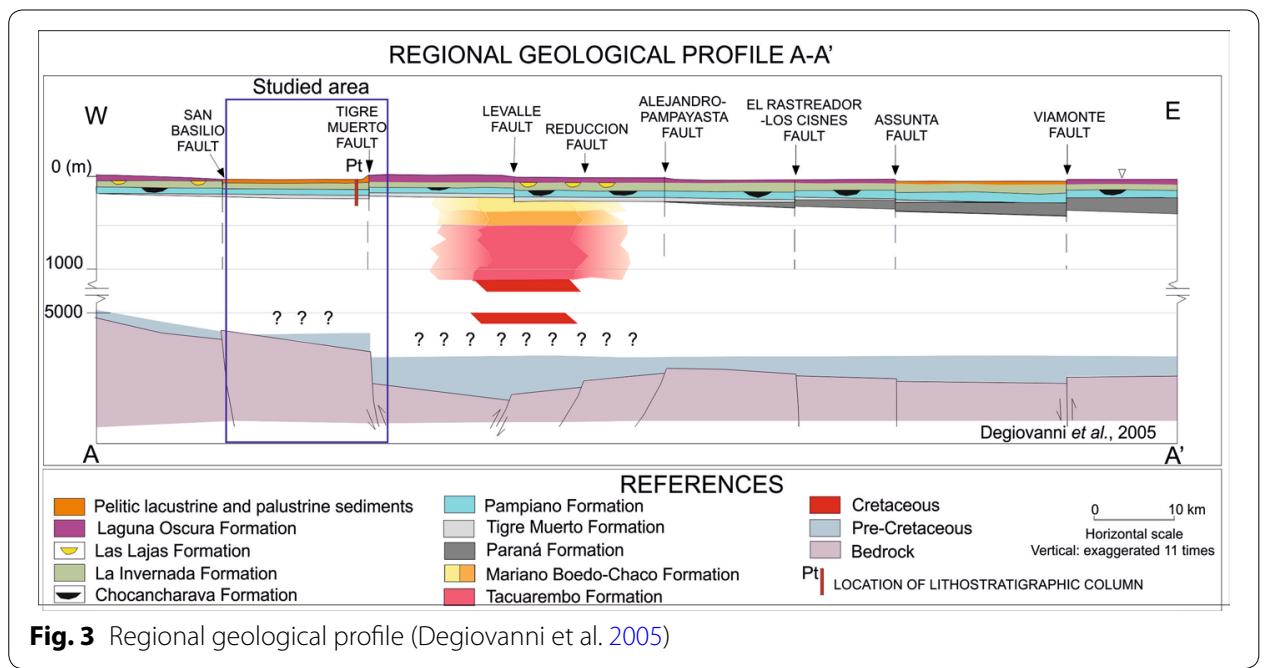

The coarser Neogene sediments are linked to fluvial systems whose upper basin was located in the Comechingones Mountains, which had an important orogenic activity in that geological epoch (Chebli et al. 1999).

\section{Hydrolithology and hydrodynamics}

The unconfined aquifer, whose thickness is $75-100 \mathrm{~m}$, is formed by fine aeolian Quaternary sediments characterized by a hydraulic conductivity $(\mathrm{K})$ in the order of $1-5 \mathrm{~m} / \mathrm{d}$. This aquifer, with groundwater north-south flow direction and hydraulic gradients of $0.2-0.3 \%$, presents a very low water table level $(0-5 \mathrm{~m})$, which generates an area with permanent ponds. This situation is typical of regional discharge areas that receive groundwater flow coming from the piedmont and undulating plains in the northwestern region (Cabrera et al. 2012a, b). The confined aquifer systems, located at 120-350 m depth, are multilayered. There are lenses of variable size and textural features, related to the different stages of the Neogene fluvial paleosystems. The $\mathrm{K}$ values are higher than those in the unconfined aquifer (Table 1). The sedimentary layers that limit these aquifer systems are composed of clay, silty-clays, and highly cemented silts. The upper aquifer layer (A1 CAS), covered by silts sediments, has the lowest confinement grade. The deepest aquifer layer (A2 CAS) has a top covering layer of clay sediments and exhibits greater confinement, especially towards the south of the area. The sedimentological features made it possible to distinguish two subsystems A2a CAS, to the north, and A2b CAS, to the south (Fig. 5). All deep aquifer systems present higher piezometric level than the unconfined aquifer, having the system A2b CAS the highest hydraulic head. Most wells that abstract water from these deep aquifers are artesian. Groundwater general flow direction is to the south/southeast (Fig. 5). The measured hydraulic heads and chemical results for the different wells demonstrate that in this region predominate the conditions resulting from gravity-flow systems of groundwater in the sense of Toth (2009). The average hydraulic gradients calculated for all the confined systems are in the order of $0.2 \%$ and the groundwater velocity is in the order of $0.07 \mathrm{~m} / \mathrm{d}$ (Cabrera et al. 2010) (Table 1). 


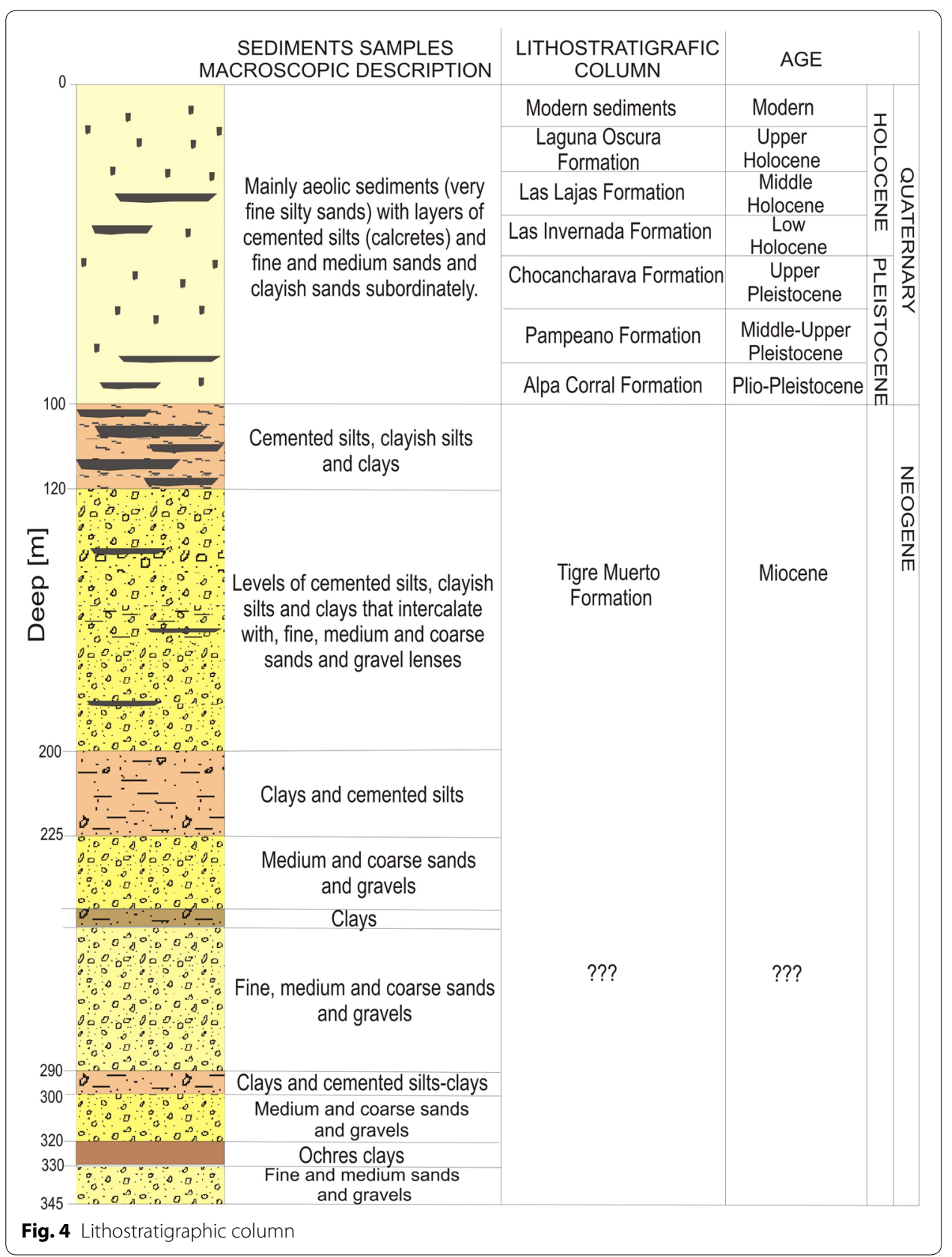

Table 1 Hydraulic features of the different aquifer systems

\begin{tabular}{|c|c|c|c|c|c|c|}
\hline $\begin{array}{l}\text { Hydraulic } \\
\text { occurrence }\end{array}$ & & Depth (m) & $\begin{array}{l}\text { Hydraulic } \\
\text { conductivity } \\
\text { (K) }(\mathrm{m} / \mathrm{d})\end{array}$ & $\begin{array}{l}\text { Effective } \\
\text { porosity (ep) } \\
\text { (\%) }\end{array}$ & $\begin{array}{l}\text { Hydraulic } \\
\text { gradients } \\
\text { (\%) }\end{array}$ & $\begin{array}{l}\text { Groundwater } \\
\text { velocity }(\mathrm{m} / \mathrm{d})\end{array}$ \\
\hline $\begin{array}{l}\text { Unconfined } \\
\text { aquifer }\end{array}$ & & Up to $75-100$ & $1-5$ & $5-10$ & $0.2-0.3$ & $0.04-0.2$ \\
\hline \multirow{2}{*}{$\begin{array}{l}\text { Confined aquifer } \\
\text { systems }\end{array}$} & A1CAS & $120-200$ & $2-8$ & $15-20$ & $0.2-0.3$ & $0.03-0.12$ \\
\hline & A2CAS & $225-350$ & $5-10$ & $20-30$ & $0.1-0.3$ & $0.025-0.1$ \\
\hline
\end{tabular}




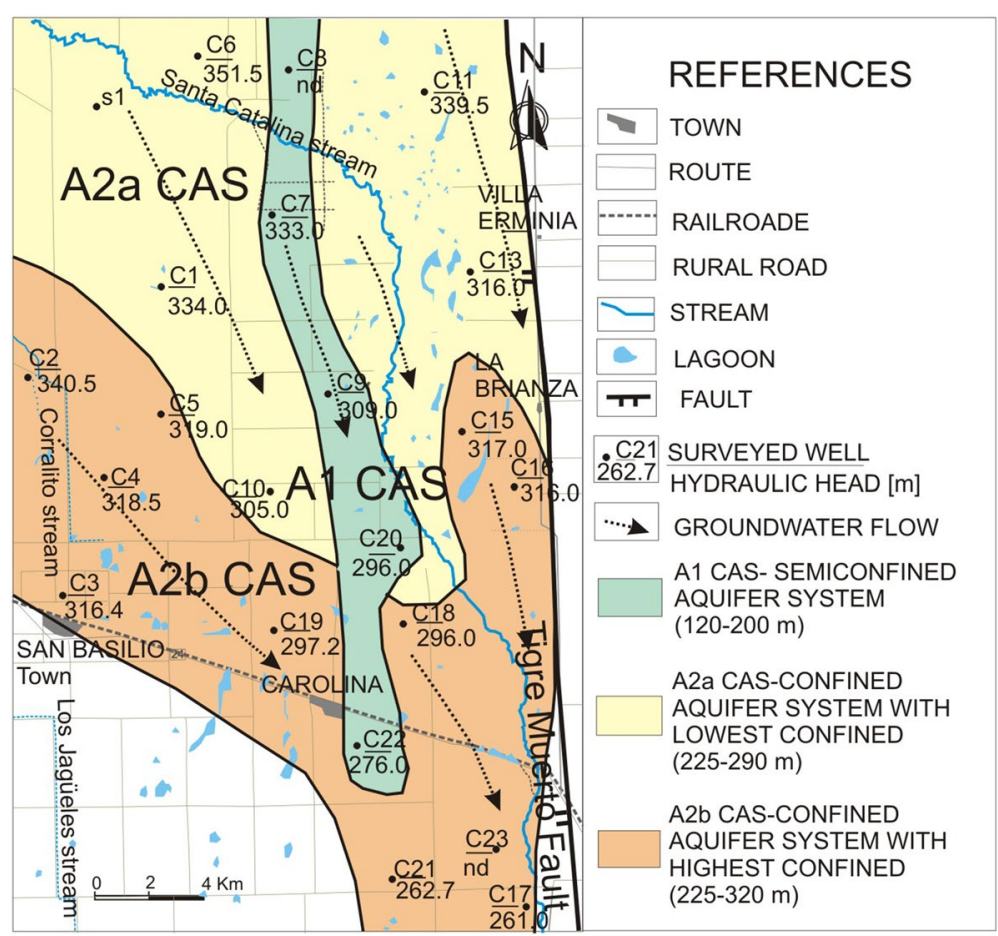

Fig. 5 Areal distribution of confined aquifer systems

\section{Hydrogeochemistry, isotope features, and groundwater age estimation}

All confined aquifer systems present fresh groundwater (Table 2), a feature related to the textural and mineralogical (predominantly quartz) characteristics of the fluvial deposits that make up the aquifer layers. All the samples resulted of sulfate geochemical type.

In relation to the isotopic analysis, deep thermal groundwater does not show a relationship with magmatic waters whose typical $\delta^{18} \mathrm{O}$ values are between +8 and $+12.8 \%$ and $\delta^{2} \mathrm{H}$ values between -29 and $-99 \%$ (Mark et al. 2004). Thus, the origin is clearly linked to the recharge of meteoric waters (Table 2; Fig. 6). The systems with lower confinement grade (A1 and A2a CAS) present the saltiest waters (CE between 1800 and $3050 \mu \mathrm{S} / \mathrm{cm}$ ). Moreover, they show a slightly depleted isotopic composition (Fig. 6) in relation to the local rainfall $\left(\delta^{18} \mathrm{O}=-4.4 \%\right.$; $\delta^{2} \mathrm{H}=-24 \%$ o but similar to the local unconfined aquifer $\left(\delta^{18} \mathrm{O}\right.$ between -5.0 and $-4.6 \%$ and $\delta^{2} \mathrm{H}$ between -32 and $-28 \%$ ) and to some streams and the unconfined aquifer located in the piedmont region. The piedmont water has depleted values because it receives recharge from Atlantic rainfalls that, when entering the continent in E-W direction, suffer isotopic impoverishment as a result of typical continental and altitude effects (Figs. 1, 7) (Cabrera et al. 2010).

The isotopic similarity of A1 CAS with the unconfined aquifer would suggest hydraulic connection between systems. However, and taking into account that in the studied area all the wells are artesian, the hydraulic connection may have occurred nearby the piedmont where the hydraulic relationship is inverted. In contrast, the relationship may be local and the supply may go from A1 CAS aquifer to the unconfined one.

The similarity of isotopic composition between A1 and A2a CAS with the surface and groundwater of the piedmont areas of the Comechingones Mountains makes it possible 


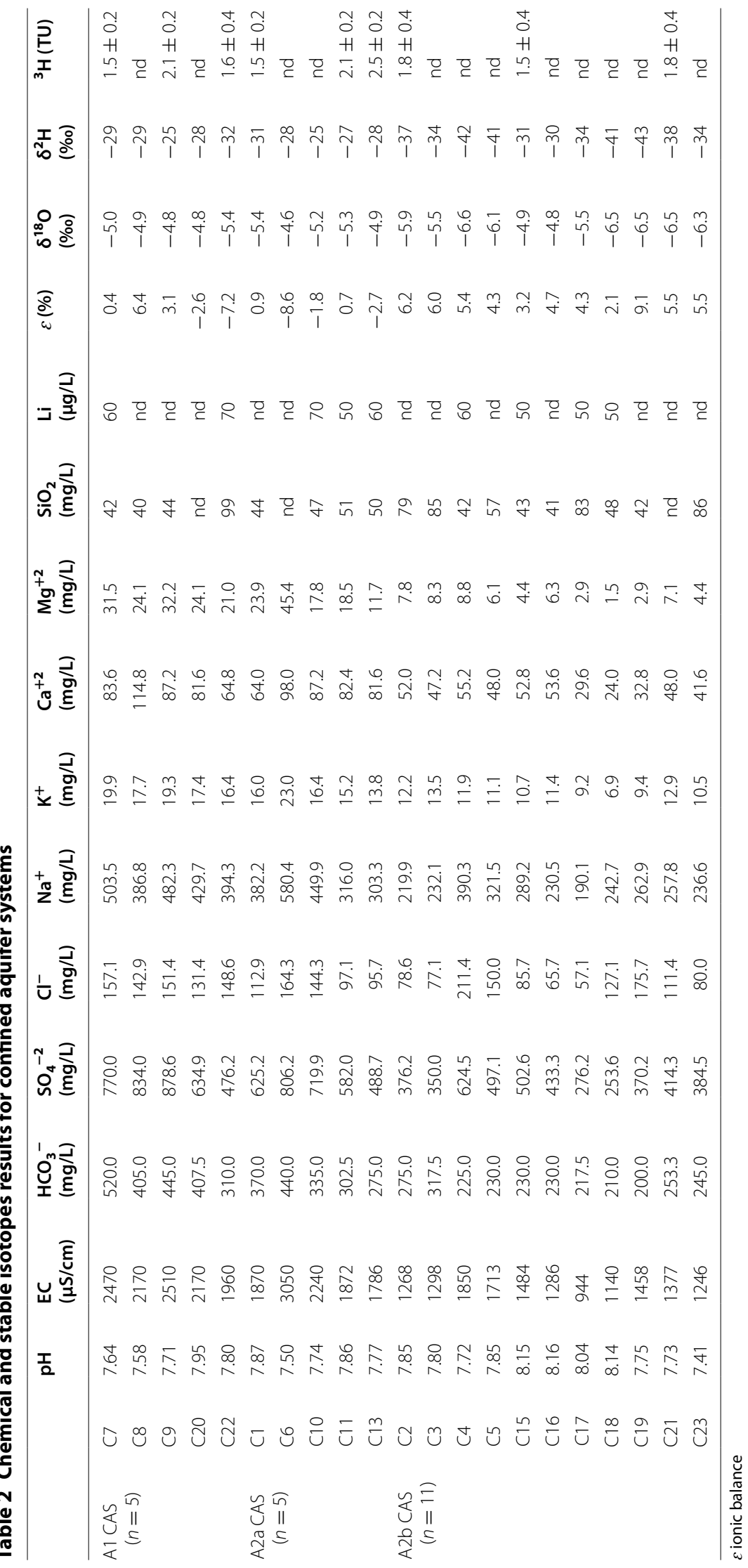




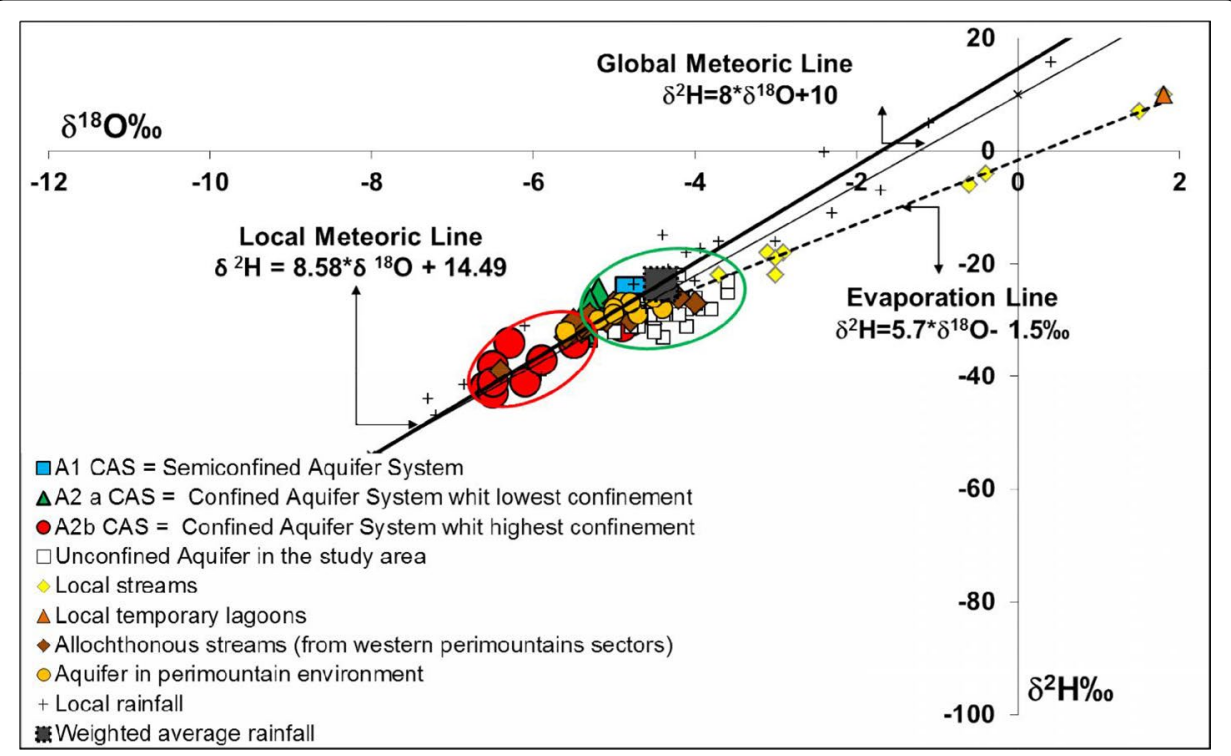

Fig. $6 \delta^{18} \mathrm{O}$ vs $\delta^{2} \mathrm{H}$ : showing isotopic composition of water systems (Cabrera 2009)

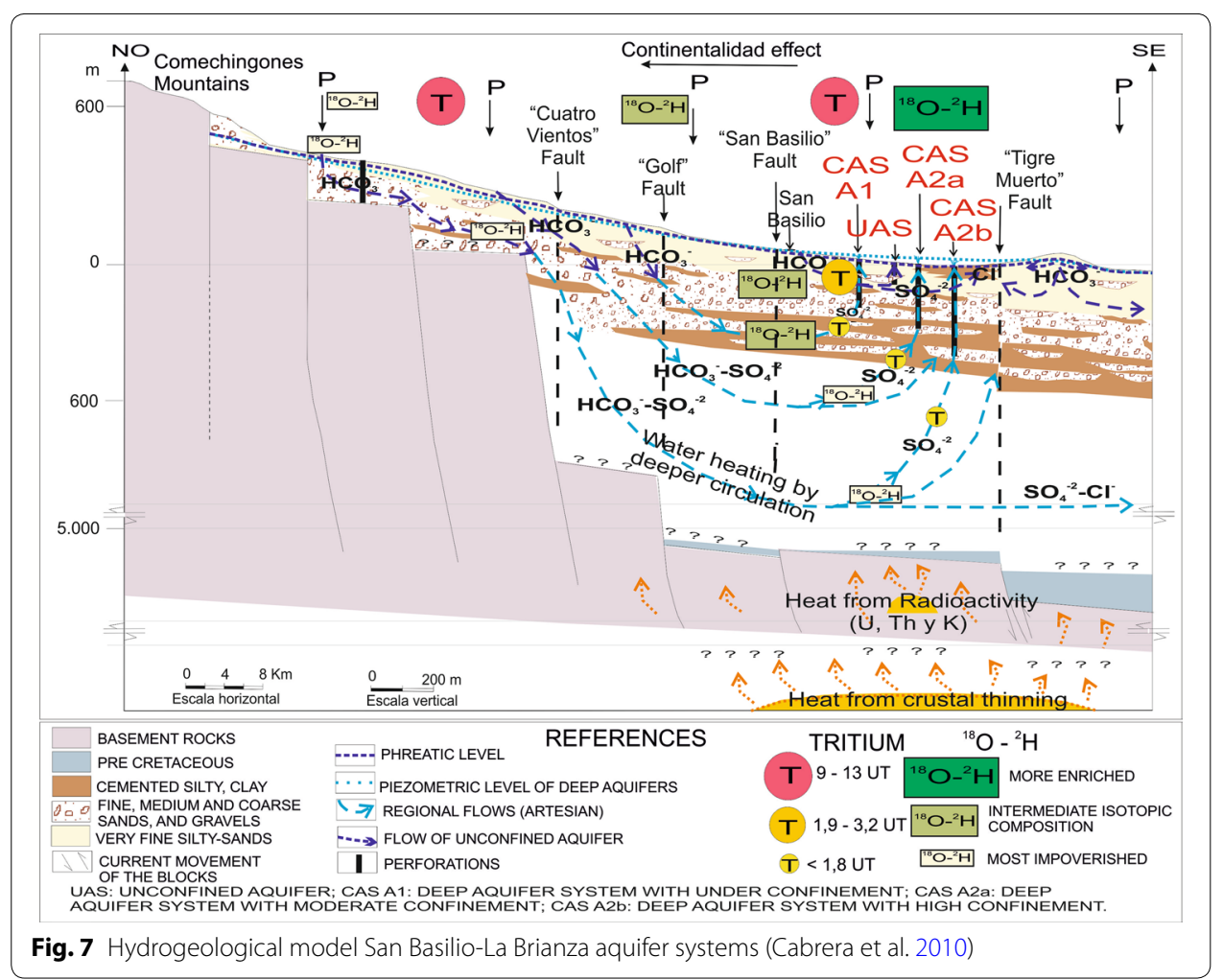

to assume allochthonous recharge. Moreover, the existence of old waters in the studied area may be interpreted if the long distance to the recharge piedmont area (approximately $80 \mathrm{~km}$ ) and the estimated groundwater velocity in the confined systems (about $0.07 \mathrm{~m} / \mathrm{d}$ ) are taking into consideration. 
Notably, the freshest groundwater $(944-1850 \mu \mathrm{S} / \mathrm{cm})$ is the one found in the deepest system (A2b CAS). Also, it has more depleted isotopic values $\left(\delta^{18} \mathrm{O} \approx-6.6 \%\right.$; $\delta^{2} \mathrm{H} \approx-43 \%$ ) than the overlying systems (Table 2; Fig. 6) which indicates a disconnection between them and also allochthonous recharge coming from the western area. That is to say, they have similar isotopic signatures to the rivers and streams located in the Comechingones Mountains and piedmont areas which are fed by depleted Atlantic rains, as was previously stated (Cabrera et al. 2010).

The hydraulic method suggests ages in the order of 3000 years (between 1500 and 7000 years) for the A1 CAS system and in the order of 4000 years (between 2000 and 9000 years) for deeper systems (A2a and A2b CASs).

The low activity of ${ }^{3} \mathrm{H}$ in groundwater of confined systems $(<2.5$ UT) suggests that they are old waters recharged before the 1950s, that is to say, older than 60 years.

The ${ }^{14} \mathrm{C}$ ages (Table 3; Fig. 8) have been corrected taking into account ${ }^{13} \mathrm{C}$ values in each sample. The low values of $\delta^{13} \mathrm{C}$ that show more ${ }^{13} \mathrm{C}$ enriched waters than the expected for the present atmospheric $\mathrm{CO}_{2}$ (approximately $-7.5 \%$ ) would be indicating either old waters (pre-bomb) when the atmospheric values were more enriched (about $-6.5 \%$ ) and/or the influence of continental carbonate dissolution. This dissolution process would supply $\delta^{13} \mathrm{C}$ between 0 and $-6 \%$. Later, some corrections were carried out considering not only the influence of the dissolution of carbonates but also the isotopic exchange (Pearson-Gonfiantini) (Table 3).

Table $3{ }^{14} \mathrm{C}$ ages water confined aquifer systems

\begin{tabular}{lllcccc}
\hline Sample & Aquifer system & $\mathbf{\delta}^{\mathbf{1 3}} \mathbf{C}(\mathbf{\% o})$ & ${ }^{\mathbf{1 4}} \mathbf{A ~ p m C}$ & ${ }^{\mathbf{1 4}} \mathbf{C}$ Age (BP) & Tamers (BP) & $\begin{array}{l}\text { Pearson-Gonfiantini (BP) } \\
\boldsymbol{\varepsilon}=-\mathbf{8 . 4 6}\end{array}$ \\
\hline C22 & A1 CAS & -5.01 & 26.74 & 10,596 & 5526 & 2238 \\
C13 & A2a CAS & -6.07 & 45.66 & 6298 & 1129 & -603 \\
C4 & A2b CAS & -6.38 & 8.22 & 20,069 & 15,344 & 13,983 \\
C15 & A2b CAS & -6.56 & 40.34 & 7293 & 1938 & 1061 \\
C19 & A2b CAS & -7.15 & 3.01 & 28,136 & 23,619 & 23,220 \\
\hline
\end{tabular}

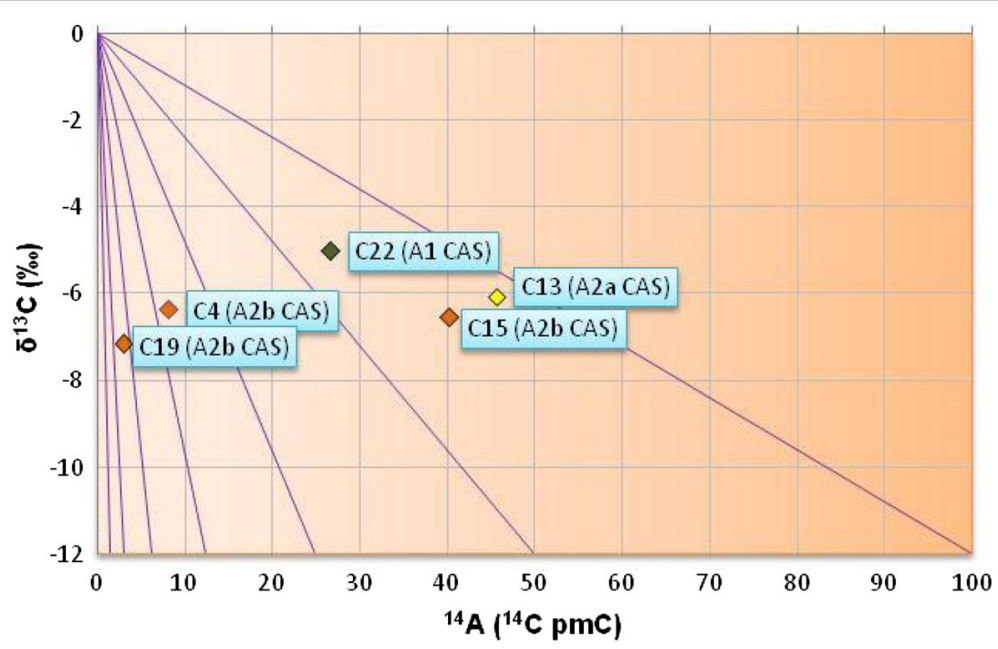

Fig. $8{ }^{14} \mathrm{C}$ isochrones for study area samples 
Taking into account the geochemical features of these confined systems $(2-3 \mathrm{mg} / \mathrm{L}$ of dissolved oxygen and huge amounts of dissolved sulfate) and in spite of being geothermal waters, evidences of the processes like methanogenesis, sulfate reduction, denitrification, or anaerobic oxidation of organic matter were not identified. Therefore, it is assumed that dead $\mathrm{C}$ from carbonate dissolution is the main cause of decreased ${ }^{14} \mathrm{C}$ activity.

In this way, the corrected ${ }^{14} \mathrm{C}$ values indicate an age between 2000 and $5000 \mathrm{BP}$ for the A1 CAS and between 1000 and 23,000 BP for A2 CAS (Table 3). Younger ages estimated for groundwater in C13 well (A2a CAS) and C15 well (A2b CAS), even lower than those estimated with hydraulic methods, would be related to groundwater mixtures with the overlying systems, which confirms the interpretation from stable isotopes. However, it must be taken into account that this anomalous situation is also linked to the fact that some wells have been permanently opened for more than 50 years. Therefore, it is supposed that the oldest groundwater has already been drained (C15 well). The highest radiocarbon ages resulted higher than those obtained with the hydraulic method, probably because depth and confinement of A2 CAS may generate lower K values. Moreover, the hydraulic method only takes into account the advection process, whereas the age is affected by hydrodynamic dispersion then, the methods may produce similar results but never the same. It is important to highlight that to improve these interpretations more data of groundwater ages are needed.

\section{Geothermal model}

The confined aquifer systems present hypo- to meso-thermal groundwater characterized by temperatures between 23.3 and $35.8{ }^{\circ} \mathrm{C}$ (average $=31.5^{\circ} \mathrm{C}$ ). This implies a groundwater temperature that exceeds between 1.3 and $10.3{ }^{\circ} \mathrm{C}$ the expected value for that depth, if normal gradients are considered (Table 4). This geothermal anomaly is shown in Fig. 7. The geothermal gradients vary from 3.8 to $10.8^{\circ} \mathrm{C}$ every $100 \mathrm{~m}$ being the highest values $\left(10.8^{\circ} \mathrm{C} / 100\right)$ located in the central area (Fig. 9).

The silica geothermometer was used since the water chemistry of these CASs indicates super saturation, especially chalcedony and quartz (Fig. 10). The geothermometers of amorphous $\mathrm{SiO}_{2}$ were rejected because they provide temperatures lower than those measured at field during well sampling and even lower to $0{ }^{\circ} \mathrm{C}$. Fournier et al. (1974) indicate that even though chalcedony generally controls the solubility of the silica minerals at temperatures less than $150-250{ }^{\circ} \mathrm{C}$, in some cases, where water has been in a contact with rocks at a given temperature for a relatively long time, quartz may control dissolved silica at temperatures less than $100{ }^{\circ} \mathrm{C}$. At lower temperatures, this reaction

Table 4 Main temperature features of the confined aquifer systems

\begin{tabular}{lllll}
\hline $\begin{array}{l}\text { Aquifer } \\
\text { level }\end{array}$ & Deep $(\mathbf{m})$ & $\begin{array}{l}\text { Upwelling } \\
\text { temperature }\left({ }^{\circ} \mathbf{C}\right)\end{array}$ & $\begin{array}{l}\text { Overheating } \\
\text { with depth }\left({ }^{\circ} \mathbf{C}\right)\end{array}$ & $\begin{array}{l}\text { Classification } \\
\text { by temperature }\end{array}$ \\
\hline A1 CAS & $120-200$ & $25.0-30.9$ & $5.5-9.4$ & Hypothermal \\
A2a CAS & $225-290$ & $29.0-35.3$ & $4.2-10.0$ & $\begin{array}{r}\text { Hypothermal to } \\
\text { mesothermal }\end{array}$ \\
A2b CAS & $225-320$ & $33.8-35.8$ & $7.7-9.9$ & $\begin{array}{r}\text { Hypothermal to } \\
\text { mesothermal }\end{array}$ \\
\hline
\end{tabular}




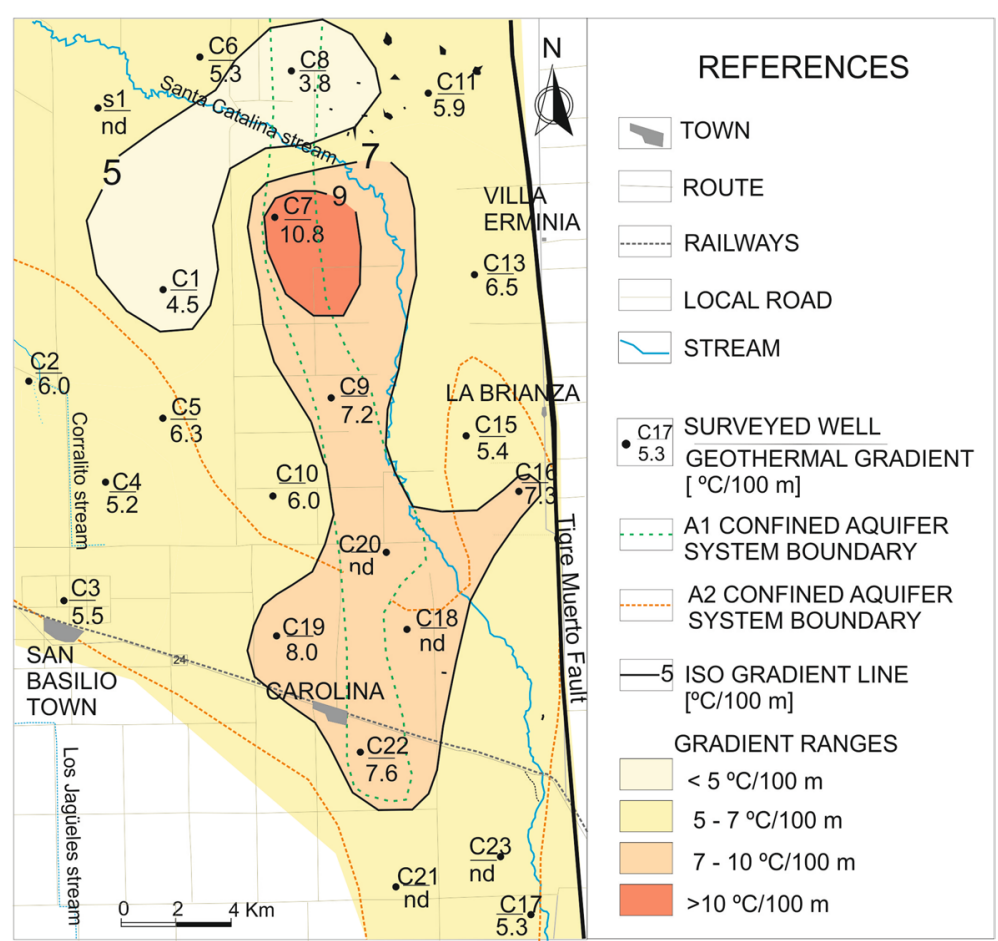

Fig. 9 Geothermal gradients

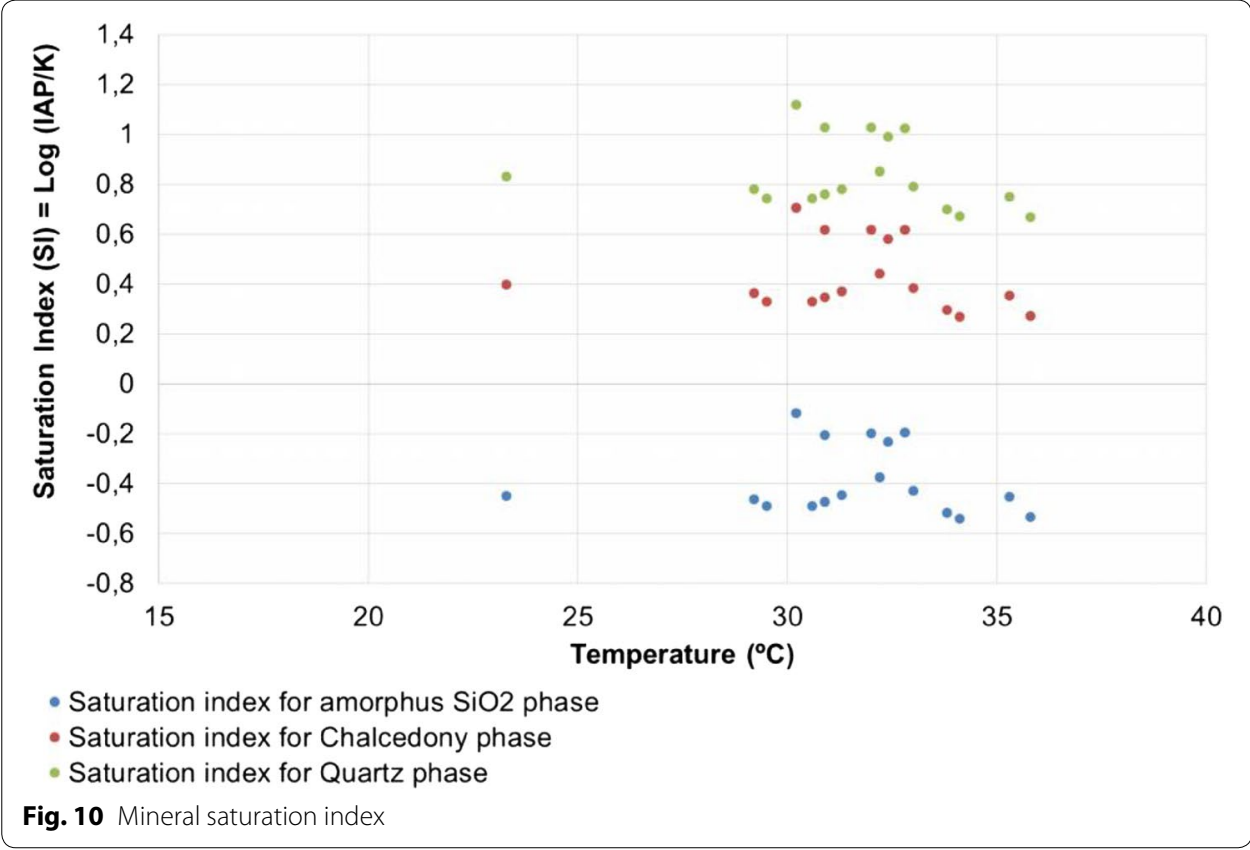

will not occur due to the slow kinetics of the reaction, although it is thermodynamically probable (Fournier et al. 1974). The geothermometers used, especially $\mathrm{SiO}_{2}$ chalcedony, show that these waters have reached mean temperatures (last thermodynamic equilibrium) of $79^{\circ} \mathrm{C}$ (Fig. 11). 


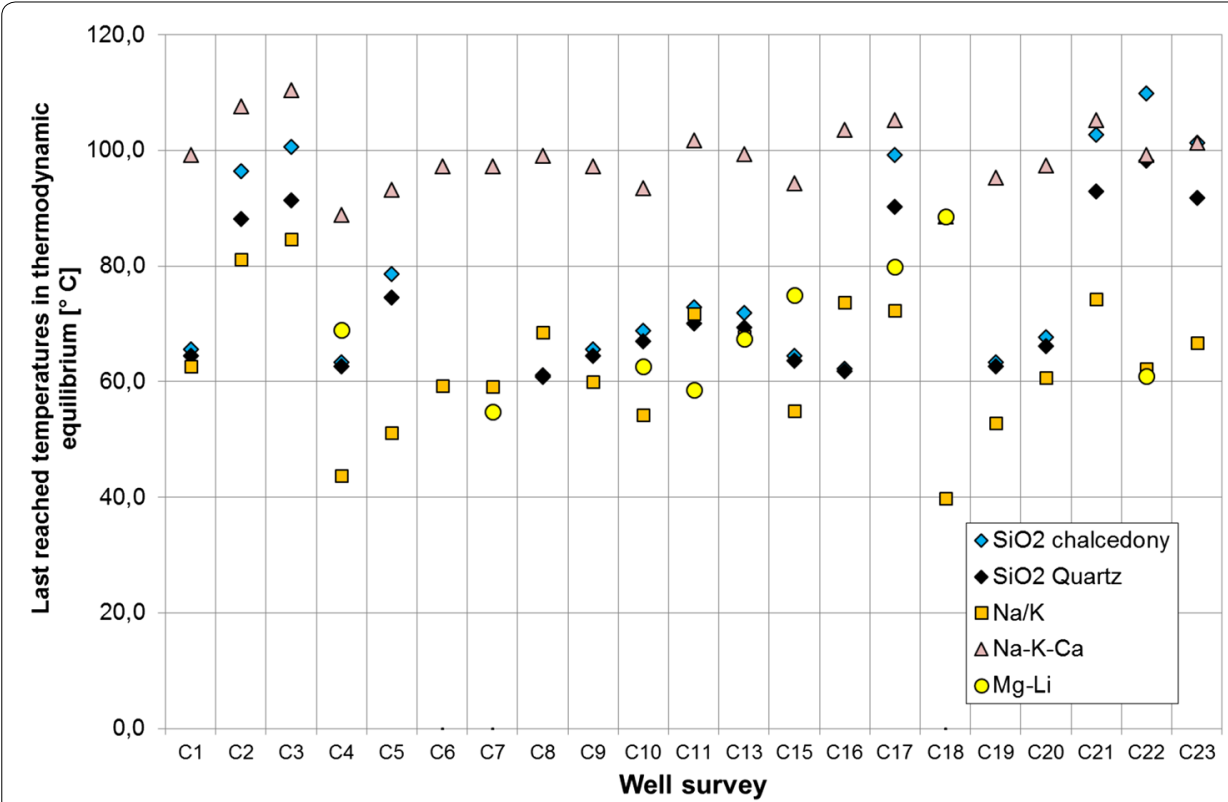

Fig. 11 Last reached temperatures in thermodynamic equilibrium. Estimated with chalcedony, quartz, Na-K, $\mathrm{Na}-\mathrm{K}-\mathrm{Ca}$, and $\mathrm{Mg}$-Li geothermometers

The $\mathrm{Cl}-\mathrm{SO}_{4}-\mathrm{HCO}_{3}$ ternary diagram indicates steam-heated waters (Fig. 12a). According to literature, the steam-heated waters have never been in the deep geothermal system but provide geothermal manifestation and physical condition of geothermal system (Arnórsson 2000).

The cationic geothermometers were used in order to compare results and to get an overview of the temperatures that the hydrothermal fluids could have reached. However, they were rejected because in the $\mathrm{Na}-\mathrm{K}-\mathrm{Mg}$ ternary diagram (Fig. 12b), although the samples are located near the boundaries of the partially equilibrated waters, they are in the immature waters field (Giggenbach 1986). Fournier and Truesdell (1973) indicate that these geothermometers, ion exchange reactions fluid-rock based, appear to give erratic results for waters from reservoirs at less than $200{ }^{\circ} \mathrm{C}$ due to different chemical reactions, i.e., precipitation of calcium as carbonate, $\mathrm{Na}-\mathrm{Ca}$ exchange clays, among others.

The maximum temperatures that these fluids must have reached would suggest that groundwater flowed from recharge areas and reached greater depths and highest temperatures than those measured during well sampling (Fig. 7). This is also evidenced by the slight oversaturation in $\mathrm{SiO}_{2}$ (mainly chalcedony) that groundwater presents when it reaches lower temperatures in more shallow environments. In this way, the temperatures that should have reached these hydrothermal fluids in order to achieve their present composition lead us to estimate that these fluids must have descended between $486 \mathrm{~m}$ and $1562 \mathrm{~m}$ (average $=1018 \mathrm{~m}$ ).

According to Blarasin et al. (2014) and Chiodi et al. (2014), the hydrothermalism in the area presents a strong geotectonic-structural conditioning, and it can be the result of the continental crustal thinning (Gimenez et al. 2011; Calegari et al. 2014). Thus, it may produce a geothermal anomaly and the regional geological faults (Kostadinoff and Reartes 

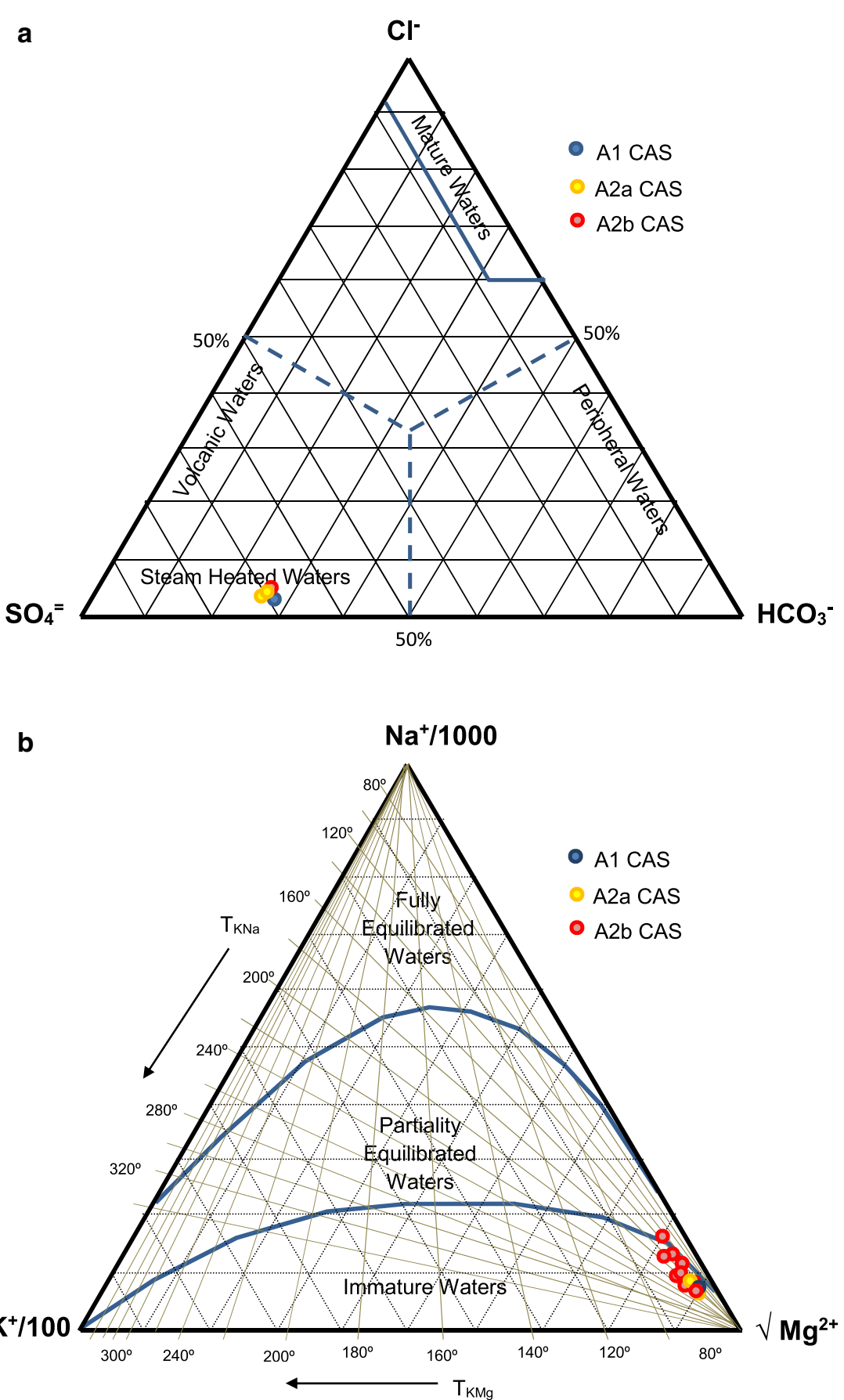

Fig. 12 a Cl- $\mathrm{SO}_{4}-\mathrm{HCO}_{3}$ ternary diagram (Giggenbach 1991). b Na-K-Mg ternary diagram (Giggenbach 1988)

1993) may be the most appropriate ways for groundwater circulation to several depths and the resulting heat transfer. Different hypotheses must be investigated in the future, for example, the presence of bedrock formed by granitic rocks (with $\mathrm{U}$, Th, K, Llambias 2008; Rapella and Baldo 2014) that may produce high internal radiogenic heat over long 
time periods. Following Donaldson (1962), other probable hypothesis to be investigated is that the heat transference may be possible in these systems through sediments that underlie the aquifer and the distribution of heat in the aquifer system itself may become possible by free hydrothermal convection.

\section{Conclusions}

The geochemical and isotopic analyses show that the groundwater has meteoric origin being recharged in the mountain and piedmont western areas (Comechingones Mountains). The absence of ${ }^{3} \mathrm{H}$ in most groundwater samples from the confined systems suggests that they are old waters not directly related to the present hydrological cycle. The ${ }^{14} \mathrm{C}$ ages obtained for A1 and A2 CASs indicate waters recharged during Holocene cold periods, between the "Little Ice Age" and the ending of "Holocene Climatic Optimum," and during the last glaciation, respectively.

The registered thermal anomaly defines a geothermal area with the highest values linked to the General Levalle Cretaceous depocenter, especially associated to the low block of the Tigre Muerto regional fault. This geothermal anomaly is consistent with the regional geotectonic setting and it is the result of the continental crustal thinning and the geological regional faults that make groundwater circulation easy at several depths. The groundwater flowing from recharge areas, favored by the dipping regional blocks, would have reached higher temperatures (in the order of $79{ }^{\circ} \mathrm{C}$, according to the chalcedony geothermometer) explaining the present oversaturation in $\mathrm{SiO}_{2}$. This situation implies maximum depths up to $1500 \mathrm{~m}$ and the observed thermodynamic behavior for such mineralogical phases. This framework is in agreement with the $\mathrm{Cl}-\mathrm{SO}_{4}-\mathrm{HCO}_{3}$ ternary diagram which indicates steam-heated waters. Moreover, the results obtained in the $\mathrm{Na}-\mathrm{K}-\mathrm{Mg}$ ternary diagram show that the cationic geothermometers were not useful because the samples were located in the immature water field near the boundary of the partially equilibrated waters.

In relation to the groundwater extraction rhythms, although the piezometric levels have been locally decreased, no significant changes have been observed in the past 20 years. Nonetheless, it is worth highlighting that the groundwater that is being used was recharged thousands of years ago, which should be taken seriously into account if a sustainable groundwater management is desired.

More studies are needed to improve the knowledge about these confined aquifers, then it is necessary to have more information about hydraulic aquifer parameters and piezometric level monitoring.

\section{Authors' contributions}

AC and MB carried out the field survey. AC processed the geological, hydrogeological, hydrochemical, isotopic, and geothermal data and has made the maps and profiles for the manuscript. MB furthermore participated in the interpretation of data and results and reviewed literature for the manuscript. LM carried out isotopical and groundwater age estimation. All authors read and approved the final manuscript.

Author details

${ }^{1}$ Dpto. de Geología, Universidad Nacional de Río Cuarto (UNRC), Ruta Nacional 36, Km 601, Río Cuarto, Córdoba, Argentina. ${ }^{2}$ CONICET (Consejo Nacional de Investigaciones Científicas y Técnicas), UNRC, Ruta Nacional 36, Km 601, Río Cuarto, Córdoba, Argentina.

Competing interests

The authors declare that they have no competing interests. 


\section{Funding}

This paper was supported by FONCyT-MINCyT Cordoba PID 35/08, UNRC and partially by IAEA Research Contract ARG: 17385; CRP F33020.

\section{Publisher's Note}

Springer Nature remains neutral with regard to jurisdictional claims in published maps and institutional affiliations.

Received: 10 August 2016 Accepted: 7 June 2017

Published online: 13 June 2017

\section{References}

Albu M, Banks D, Nash H. Mineral and thermal groundwater resources. London: Chapman \& Hall; 1997.

APHA, AWWA, WPCF. American Public Health Association \& Eaton, Andrew D \& Water Environment Federation \& American Water Works Association. Standard methods for the examination of water and wastewater, 21 st. Washington, D.C.; 2005.

Arnórsson S. Isotopic and chemical techniques in geothermal exploration, development and use. Sampling methods, data handling and interpretation. Vienna: International Atomic Energy Agency; 2000. p. 351.

Blarasin M, Cabrera A, Matteoda E, editors. Aguas subterráneas de la provincia de Córdoba. UniRío. Universidad Nacional de Río Cuarto. Argentina; 2014

Cabrera A. Evolución hidrogeoquímica e isotópos ambientales del sistema acuífero asociado a los ambientes morfotectónicos de la falla regional Tigre Muerto. Córdoba. Tesis doctoral. UNRC. Inédita; 2009. p. 300

Cabrera A, Blarasin M, Matteoda E. Análisis hidrodinámico, geoquímico e isotópico de base para la evaluación de sistemas hidrotermales de baja temperatura en la llanura cordobesa argentina. Revista Boletín Geológico y Minero de España. 2010;121(4):387-400.

Cabrera A, Blarasin M, Maldonado L. Modelo hidrotermal de baja entalpía en acuíferos confinados utilizando geotermómetros. Córdoba. Argentina. En: Actas del XI Congreso Latinoamericano de Hidrogeología. Cartagena de Indias. Colombia. 20-24 Agosto 2012; 2012.

Cabrera A, Blarasin M, Maldonado L. Influencia de morfoestructuras sobre la dinámica y calidad del agua subterránea de un sector de la llanura pampeana cordobesa. En: Resúmenes del V Congreso Argentino de Cuaternario y Geomorfología. Río Cuarto. Córdoba, Argentina. 2-4 Octubre 2012; 2012.

Calegari R, Chebli G, Manoni R, Lázzari V (2014) Cuencas Cretácicas de la Región Central del Pais: General Levalle. En: Relatorio del XIX Congreso Geológico Argentino. Córdoba, 2. 2-6 Junio 2014; 2014. p. 913-37.

Chebli G, Mozetic M, Rossello C, Bühler M. Cuencas Sedimentarias de la Llanura Chacopampeana. En Caminos R, editor. Geología Argentina, Servicio Geológico Minero, Instituto de Geología y Recursos Naturales, Anales, 29. Buenos Aires; 1999. p. 627-44

Chiodi A, Martino R, Báez W, Fórmica S, Fernández G. Recursos Geotérmicos de Córdoba. En: Relatorio del XIX Congreso Geológico Argentino. Córdoba, 2. 2-6 Junio 2014; 2014. p. 1179-87.

Craig H. Isotopic standards for carbon and oxygen and correction factors for mass-spectrometric analysis of carbon dioxide. Geochim Cosmochim Acta. 1957;12:133-49.

Custodio E, Llamas M. Hidrología subterránea. 2nd ed. Barcelona: Omega; 1996. p. 1-2350.

Degiovanni S, Villegas M, Blarasin M y Sagripanti G. Hoja Geológica 3363-III Río Cuarto. 1:250.000. Programa Nacional de Cartas Geológicas. Secretaría de Minería de la Nación (SEGEMAR). Boletín No 349. Argentina; 2005.

Donaldson I. Temperature gradients in the upper layers of the Earth's crust due to convective water flows. J Geophys Res. 1962;67:3449-59.

Fournier R, Truesdell A. An empirical Na-K-Ca geothermometer of natural water. Geochim Cosmochim. 1973:37:1255-75.

Fournier R, White D, Truesdell A. Geochemical indicators of subsurface temperature. Part l, basic assumptions. J Res US Geol Surv. 1974:23:259-62.

Fouillac C, Michard G. Sodium/lithium ratio in water applied to geothermometry of geothermal reservoirs. Geothermics. 1981:10:55-70.

Giggenbach WF. Geothermal solute equilibria. Derivation of Na-K-Mg-Ca geoindicators. Geochim. Cosmochim. Acta. 1988;52(12):2749-65

Giggenbach WF. Graphical techniques for the evaluated water/rock equilibration conditions by use of $\mathrm{Na}, \mathrm{K}, \mathrm{Mg}$ and $\mathrm{Ca}$ contents of discharge water. Proceedings of the 8th New Zealand Geothermal Workshop; 1986. p. 37-43.

Giggenbach WF. Chemical techniques in geothermal exploration, In: D'Amore F, editor. Applications of geochemistry in geothermal reservoir development. UNITAR/UNDP publication, Rome; 1991. p. 119-45

Gimenez M, Dávila F, Astini R, Martínez P. Interpretación gravimétrica y estructura cortical en la cuenca de General Levalle, Provincia de Córdoba, Argentina. Revista Mexicana de Ciencias Geológicas. 2011;28(1):105-17.

Gonfiantini R. Standards for stable isotope measurements in natural compounds. IAEA/WMO, 2002. G. Network for isotopes in precipitation. The GNIP database. Nature. 1978;271:534-6.

Kazemi G, Lehr J, Perrochet P. Groundwater age. New Jersey: Wiley; 2006.

Kharaka Y, Mariner R. Thermal history of sedimentary basins. Methods and case histories. New York: Springer-Verlag; 1989 Kostadinoff J, Reartes W. Medición e interpretaciones del flujo de calor terrestre en el Sur de la provincia de Buenos Aires. Revista de la Asociación Geológica Argentina. 1993;48(2):147-53.

Lis G, Wassenaar L, Hendry M. High-precision laser spectroscopy D/H and ${ }^{18} \mathrm{O} /{ }^{16} \mathrm{O}$ measurements of microliter natural water samples. Anal Chem. 2008;80(1):287-93. doi:10.1021/ac701716q.

Llambias E. Geología de los cuerpos ígneos. Revista de la Asociación Geológica Argentina. Serie B. Didáctica y complementaria 29. Bs. As; 2008. 
Mark G, Foster D, Pollard P, Williams P, Tolman J, Darvall M, Blake K. Stable isotope evidence for magmatic fluid input during large-scale $\mathrm{Na}-\mathrm{Ca}$ alteration in the Cloncurry Fe oxide Cu-Au district, NW Quensland, Australia. Terra Nova. 2004;16(2):45-89.

Maldonado L, Blarasin M, Cabrera A, Panarello H, Dapeña C. Assessing groundwater age in confined aquifers from the central Pampean plain of Córdoba, Argentina. Radiocarbon. 2016. doi:10.1017/RDC.2016.35.

Pérez M, Tujchneider O, Paris M, D'Elia M. Estimación de la conductividad hidráulica a partir de datos granulométricos. Actas de XIX Congreso Geológico Argentino. Martino R, Lira R, Guereschi A, Baldo E, Franzese J, Krohling D, Manassero M, Ortega G, Pinotti L, editors. Córdoba, Argentina; 2014.

Pesce A. Web SEGEMAR. 2008. http://www.segemar.gov.ar/geotermia/geoter.htm.

Pieters P, Skirrow R. Informe geológico y metalogenético de las sierras de San Luis y Comechingones, provincia de San Luis y Córdoba. Servicio Geológico Minero Argentino. Proyecto de Cooperación Argentino-Australiano, Buenos Aires. Argentina; 1997. p. 129.

Ramos V. Rasgos Estructurales del Territorio Argentino. RAGA-Revista de la Asociación Geológica Argentina. Instituto de Geología y Recursos Minerales. 1999;29(24):715-84.

Rapela C, Pankhurst R, Casquet C, Fanning C, Baldo E, Gónzalez Casado J, Galindo C, Dahlquist J. The Río de la Plata craton and the assembly of SW Gondwana. Earth Sci Rev. 2007;83(1-2):49-82.

Rapela C, Baldo E. El cratón del Río de la Plata en la provincia de Córdoba. Relatorio del XIX Congreso Geológico Argentino. Córdoba, Argentina; 2014. p. 871-80.

Reinante S, Olivieri G, Salinas A, Lovechio J, Basile Y. La cuenca Chacoparaná: estratigrafía y recursos de hidrocarborus. XIX Congreso Geológico Argentino. Córdoba, Argentina; 2014. p. 895-912.

Salem O, Visser J, Dray M, Gonfiantini R. Groundwater flow patterns in the Western Lybiam Arab Jamahiriya evaluated from isotope data. In: Investigations with isotope techniques. international atomic energy agency. Vienna; 1980. p. $165-80$.

Schafmeister M. What grains can tell on Darcy velocity? International Symposium Aquifers Systems Management. Dijon, France, Communication DARCY-126, CD ROM edition; 2006.

Sekento L R (2012) Geochemical and isotopic study of the Menengai geothermal field, Kenya. Report 31 in: Geothermal Training in Iceland 2012. UNU-GTP, Iceland, 769-92.

Sigismondi M, Fantín F. Estructura cortical y características geodinámicas. XIX Congreso Geológico Argentino. Córdoba, Argentina; 2014. p. 939-61.

Stober I, Bucher K. Geothermal energy. Berlin: Springer-Verlag; 2013.

Tamers M. Validity of radiocarbon dates on groundwater. Geophys Surv. 1975;2:217-39.

Tóth J. Gravitational systems of groundwater flow. Theory, evaluation, utilization. Cambridge: Cambridge University Press; 2009. p. 297.

Webster R, Chebli G, Fischer J. General Levalle basin, Argentina: a frontier Lower Cretaceous rift basin. Am Assoc Petrol Geol Bull. 2004;88:627-52.

Vasilyev G, Peskov N, Gornov V, Kolesova M. The effectiveness of low-grade geothermal heat usage under the conditions of the Russian climate. Geothermics. 2016;62:93-102.

\section{Submit your manuscript to a SpringerOpen ${ }^{\odot}$ journal and benefit from:}

- Convenient online submission

- Rigorous peer review

- Open access: articles freely available online

- High visibility within the field

Retaining the copyright to your article

Submit your next manuscript at $\gg$ springeropen.com 